\title{
The Mechanics of Intervention in Exchange Markets
}

\author{
ANATOL B. BALBACH
}

O January 4, 1978 the Treasury and the Federal Reserve System, in conjunction with the Exchange Stabilization Fund, announced that they would intervene in foreign exchange markets to prevent a speculative decline in the international value of the U.S. dollar. "This announcement has been happily received by European and Japanese central banks and has elicited lively discussion in the news media. The stated purpose of intervention is to eliminate "speculative" swings in the value of the dollar. But it is also clear that if such speculation has indeed affected the value of the dollar, it has been unidirectional for the past nine months as the international value of the dollar has been declining steadily and, at times, precipitously. This has been particularly true with respect to the Deutsche mark, Swiss franc, British pound and Japanese yen. Thus intervention in this article is viewed as the buying of dollars in foreign exchange markets by U.S, and foreign governments and central banks.

There have been many assertions with respect to the issue of intervention. There are those who argue that U.S. intervention will have contractionary effects on the U.S. money stock and will not cause expansionary pressures on the money stock of other countries. It is also argued that U.S. intervention will produce a different impact on U.S. interest rates than that produced by foreign intervention. The purpose of this article is to consider the validity of these propositions by examining the mechanics of intervention in foreign exchange markets. The issue discussed here is not whether intervention is desirable or whether it is, or will be, successful. Nor is the purpose to evaluate what ultimate impact it will have on economic activity in the United States and abroad.

\section{The Framework for Analysis}

To isolate the impact of foreign exchange intervention on U.S. and foreign money stocks and U.S. interest rates, without getting involved in possible or probable reactions by fiscal and monetary authorities, four assumptions are made.

IFederal Reserve Press Release, January 4, 1978.
1. The U.S. Treasury deficit is unaffected by foreign exchange intervention. Specifically, this implies that if foreigners buy more Treasury securities than they did prior to intervention, fewer Covernment securities will be sold to the domestic sector. It is also assumed that Treasury deposits at Federal Reserve Banks will, on average, remain at the same level. If intervention increases these deposits, the increase will be spent or sales of Treasury securities in domestic markets will decline.

2. Monetary authorities here and abroad do not undertake monetary actions to offset the impact of intervention. This, if intervention causes domestic bank reserves to increase, permitting commercial banks to expand their loans and consequently the money stock, central banks will not start selling securities in the open market to reduce bank reserves by an equivalent amount.

3. Foreign central banks immediately convert their dollar holdings (deposits at Federal Reserve Banks) into U.S. Treasury securities.

4. Gold reserves will not be used for intervention.

The first two assumptions are dictated by the scope of this analysis. The purpose is to isolate the pressures that result from intervention, not how governments react to these pressures. The third assumption is simply consistent with historical evidence - except for gold, foreign central banks minimize their holdings of noninterest-bearing assets. And the fourth assumption arises from current practices as evidenced by swaps of the type just arranged.

Accounting techniques can be used to demonstrate the impact of intervention itself, without consideration of further repercussions. To trace the financial flows that result from intervention, the balance sheets of the U.S. Treasury, Federal Reserve Banks, and a representative Foreign Central Bank, along with the consolidated balance sheets of U.S. commercial banks and foreign commercial banks, are used." In practice, intervention in foreign exchange markets can be undertaken by three distinct institutions: foreign central banks, the Federal Reserve System, and the Ex-

This analysis conld be extended to the balance sheets of the public, but the results of intervention itself would be identical.

Page 2 
Foreign Central Bank Intervention

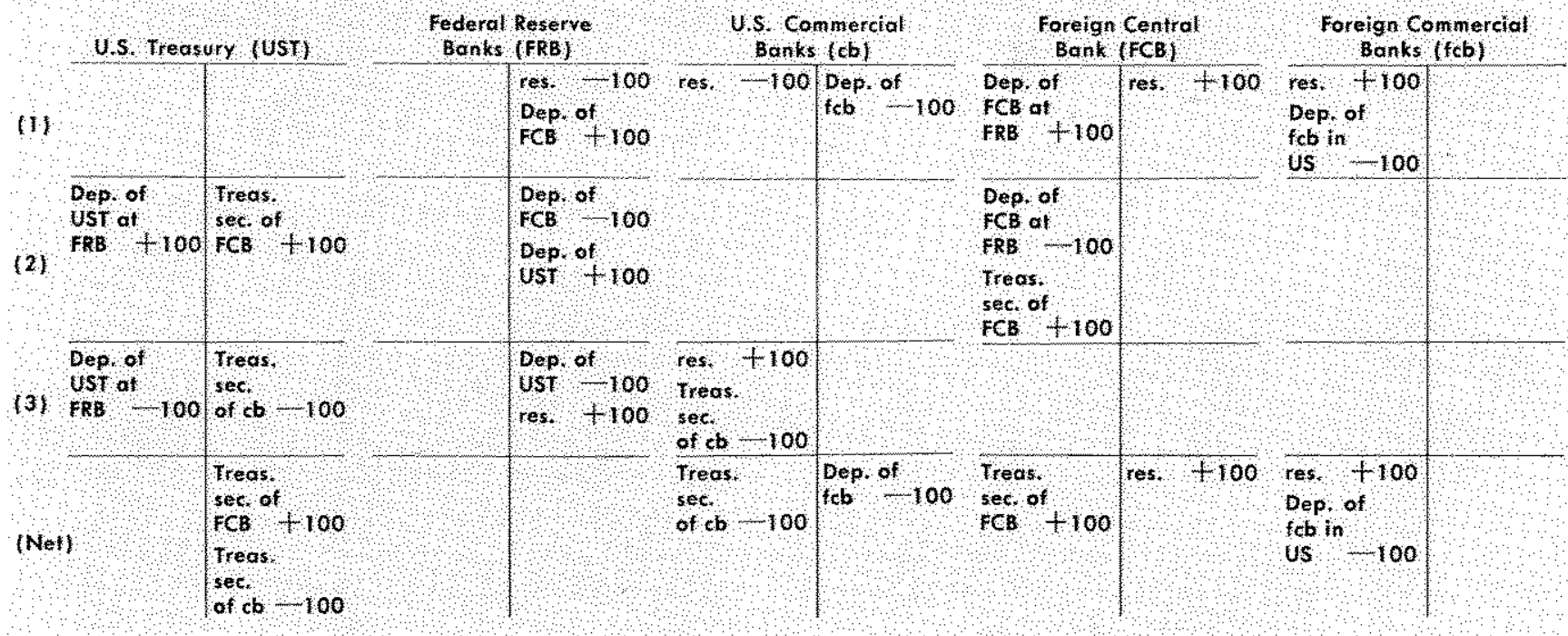

change Stabilization Fund. This last institution can intervene by using three types of assets: deposits at Federal Reserve Banks, Treasury Securities, or Special Drawing Rights (SDR) at the International Monetary Fund. Thus there are five separate cases to analyze, three of which are initiated by the Exchange Stabilization Fund.

\section{Intervention by Foreign Central Banks}

Foreign central banks can support the value of the dollar (keep their own currency from appreciating) by simply creating their own currency denominated deposits and using them to buy dollars in the foreign exchange market. Such action increases the demand for dollars on the foreign exchange market and raises the price of the dollar in terms of this foreign currency. This type of intervention was widely practiced during 1977, as foreign central banks accumulated upward of $\$ 30$ billion in dollar denominated assets.

For the sake of balance sheet brevity, the following abbreviations will be used: U.S. Treasury (UST), Federal Reserve Banks (FRB), Foreign Central Bank (FCB), Exchange Stabilization Fund (ESF), foreign commercial banks (fcb), U.S. commercial banks (cb), and commercial bank reserves (res).

In Exhibit I, transaction (1) is the process of intervention - the purchase of dollar deposits by the Foreign Central Bank. We shall assume throughout all following transactions that sellers of dollars are foreign commercial banks. This assumption is made for the sake of simplicity only, and final results would not be affected if the sellers of dollars were the U.S. or foreign public. Thus intervention in the foreign exchange market means that the Foreign Central Bank buys dollar deposits of foreign commercial banks at U.S. commercial banks and pays for them by crediting foreign commercial bank reserves. The Foreign Central Bank deposits its dollar proceeds at Federal Rem serve Banks. When this dollar draft is cleared, U.S. commercial banks lose reserves.

Transaction (2) shows the conversion of Foreign Central Bank deposits at Federal Reserve Banks into Treasury securities. It is assumed here that the Foreign Central Bank buys these securities directly from the Treasury. If it were to buy them in the open market, the final impact on reserves and interest rates would be identical. ${ }^{3}$ Thus the security holdings of the Foreign Central Bank increase, its deposits at Federal Reserve Banks decrease, and Treasury deposits at Federal Reserve Banks increase.

Since we have assumed that the Treasury will not increase the level of its deposits at Federal Reserve Banks, in transaction (3) this increase in deposits is used to buy Treasury securities from U.S. commercial banks, or more likely, the Treasury will simply sell fewer securities in domestic markets. The results of such reduced sales are equivalent to transaction (3).

The purchase of Treasury securities in the open market would increase US, commercial bank reserves. An increase in the demand for Treasury securities by the Foreign Central Bank would produce effects on interest rates identical to transaction (2) where the supply of securities was reduced. 
When U.S. commercial banks clear the check from the U.S. Treasury, their reserves rise.

The net effects of Foreign Central Bank intervention are that the Treasury has financed some of its expenditures through a sale of its securities to a Foreign Central Bank, foreign commercial bank dollar holdings have decreased, the U.S. commercial bank portfolio of Treasury securities has decreased, and foreign commercial banks have exchanged their dollar assets for domestic reserves.

Since foreign commercial bank reserves have increased, there is presstre to increase the rate of growth of the foreign money stock. U.S. commercial bank reserves have not changed, but since the Treasury has sold some of its securities directly to a Foreign Central Bank, it doesn't have to sell them in the domestic credit market. Interest rates on U.S. Govemment securities can therefore be expected to be lower than they would have been in the absence of intervention.

\section{Intervention by the Federal Reserve System}

Since intervention to prevent the dollar from declining requires foreign currencies with which to buy dollars, the swap network must be activated. Swap arrangements permit the U.S. Treasury or the Federal Reserve to borrow foreign currencies while (in effect) giving dollar denominated deposits at the Federal Reserve Banks as collateral. In practice, these deposits are usually converted into Treasury Securities, primarily of the nonnegotiable type. The acquired foreign currencies are then used to buy dollars in the foreign exchange market.
In Exhibit II, transaction (1) depicts the acquisition by the Federal Reserve System of foreign denominated deposits at the Foreign Central Bank. The Foreign Central Bank credits the Federal Reserve account and in return receives Treasury securities which are paid for by the Federal Reserve System in the form of a credit to the Treasury's account at the Federal Reserve. This transaction does not affect bank reserves in either country. In transaction (2) the Federal Reserve System buys dollar denominated deposits of foreign commercial banks at U.S. commer cial banks and pays for them with its foreign currency deposits at the Foreign Central Bank. When the Fed. eral Reserve payment is cleared, foreign commercial banks experience an increase in reserves. Meanwhile, when the foreign commercial bank draft on dollar deposits is cleared, U.S. commercial bank reserves decline. In transaction (3) the Treasury disposes of its increased balance at Federal Reserve Banks by buying Treasury securities from U.S. commercial banks (as in the previous case, this transaction is in lieu of a decrease in Treasury borrowings in private markets). This raises U.S. commercial bark reserves.

The net result of this type of intervention is identical to the one produced by Foreign Central Bank intervention: foreign commercial bank reserves expand, U.S. commercial bank reserves do not change, and there is downward pressure on the interest rates of U.S. Treasury securities.

\section{Intervention by the Exchange Stabilization Fund}

The Exchange Stabilization Fund was created in 1934 specifically for the purpose of intervening in

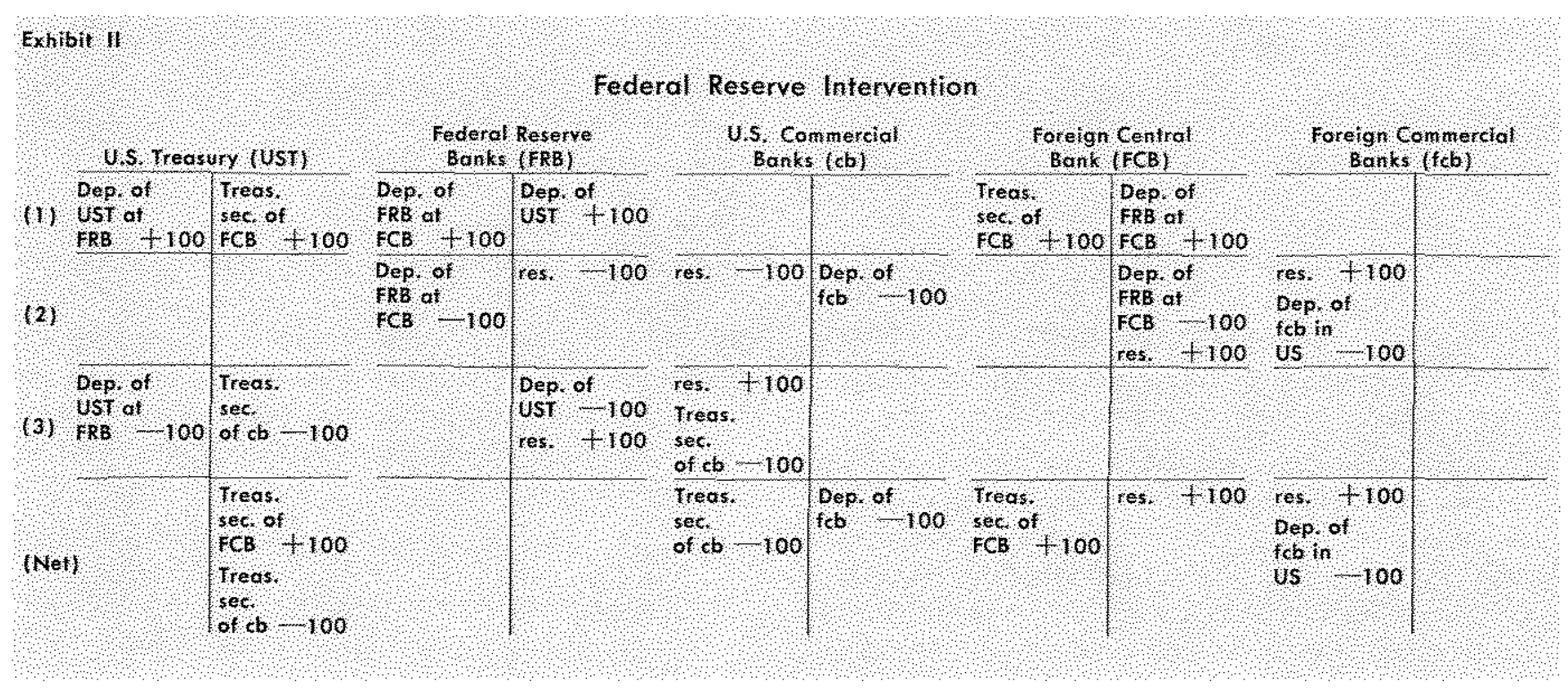




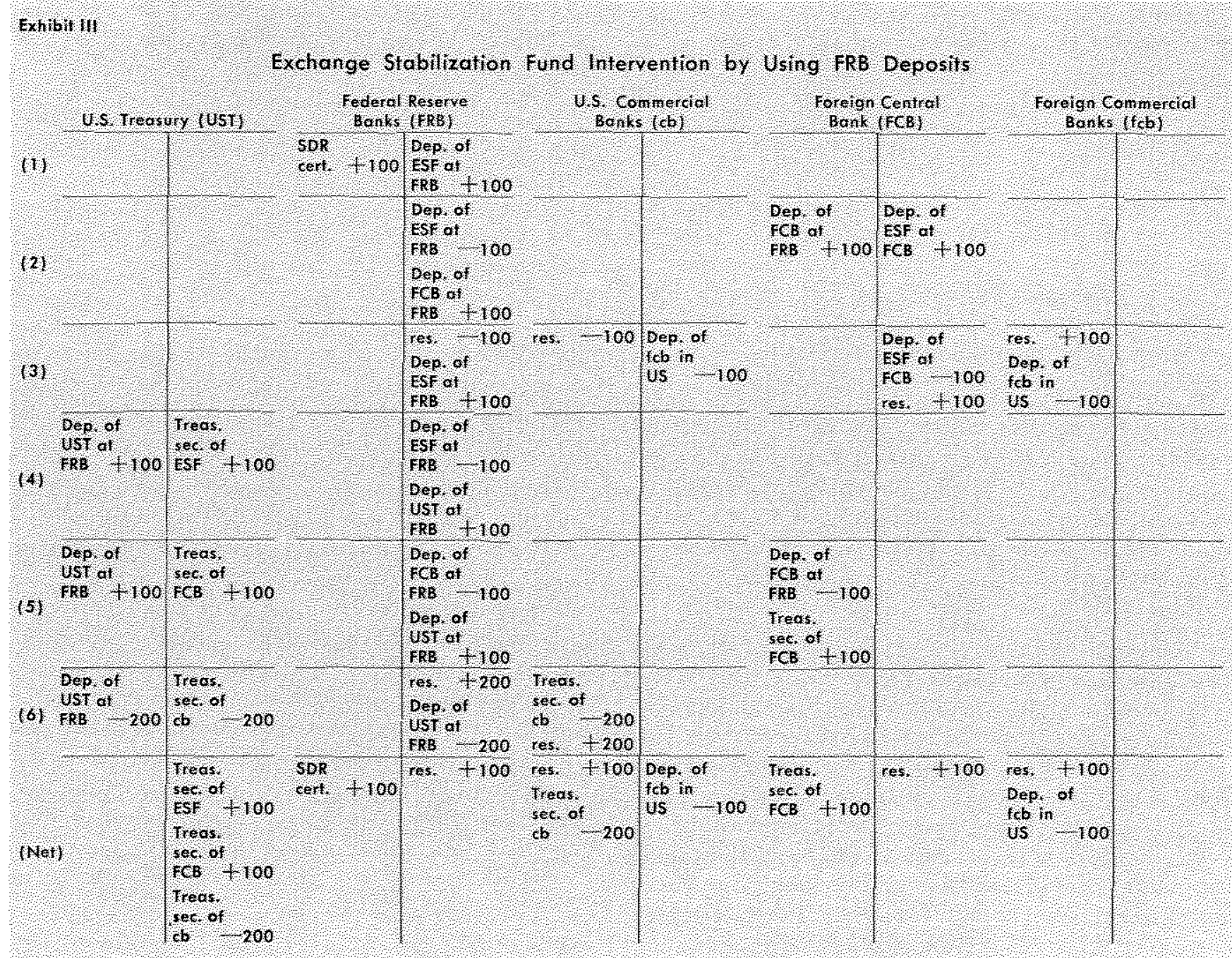

exchange markets during the fixed exchange rate regime. While the Fund is owned by the U.S. Treasury, it is a separate entity with its own financial resources and with its own account at Federal Reserve Banks. The bulk of its assets consists of Special Drawing Rights and nomegotiable Treasury securities. The impact of its intervention depends upon the type of assets that it uses. If it uses Treasury securities or its deposits at Federal Reserve Banks, then it must acquire foreign currencies in a manner similar to the Federal Reserve. If it uses SDR, which are accepted by central banks, it can sell them outright to the Foreign Central Bank for foreign currency denominated deposits. Consequently, Exchange Stabilization Fund intervention will be discussed in three parts: using deposits at Federal Reserve Banks, using Treasury securities, and using SDR. In these transactions one additional assumption must be made: the Exchange Stabilization Fund also minimizes its noninterest bearing assets and holds minimal balances at the FRB.
Using FRB Deposits - Since the Exchange Stabilization Fund has minimal deposits at the FRB, it can acquire them by selling SDR certificates to the Federal Reserve and receiving deposits in return (Exhibit III, transaction (1)). In transaction (2) the Exchange Stabilization Fund writes a check on its account at the Federal Reserve Bank and acquires foreign currency denominated deposits at the Foreign Central Bank. It then uses this account (transaction (3)) to buy dollar denominated deposits of foreign commercial banks at U.S. banks and deposits these proceeds at Federal Reserve Banks. This transaction increases foreign commercial bank reserves and reduces the reserves of U.S. commercial banks. Since the Exchange Stabilization Fund now has an increase in its balances at the Federal Reserve, it will use these balances to buy securities from the Treasury (transaction (4)). In transaction (2) the Foreign Central Bank accumulated additional deposits at Federal Reserve Banks and uses these deposits to buy securities from the 
Treasury (transaction (5)). Transactions (4) and (5) increase Treasury deposits at Federal Reserve Banks, and the Treasury uses these deposits to buy Treasury securities from U.S. commercial banks (this transaction is again in lieu of selling fewer securities in the future).

The net effect of this intervention is an increase in foreign commercial bank reserves and an increase in the reserves of U.S. commercial banks. Since the demand for Treasury securities (by the Exchange Stabilization Fund) increases and the supply decreases, these transactions produce a downward pressure on Treasury security yields.

Using Treasury Securities - This set of transactions assumes that the Exchange Stabilization Fund sells its Treasury securities directly to the Foreign Central Bank. If the Fund were to sell these securities in the open market or to the Federal Reserve System, and if Foreign Central Banks were subsequently to buy these securities, the results would be the same.

In transaction (1) of Exhibit IV, the Exchange Stabilization Fund sells its Treasury securities to the Foreign Central Bank and acquires a foreign deposit. In transaction (2) it uses its foreign currency denominated deposit to buy dollars from foreign commercial banks and deposits these dollars at its account at the Federal Reserve Bank, which causes reserves of U.S. commercial banks to contract. Intervention-induced transactions could stop here, and the net effect would be an increase in foreign commercial bank reserves and a decrease in reserves of U.S. commercial banks. There would be no effect on Treasury security yields since no securities were traded in the market.

However, the asset mix of the Exchange Stabilization Fund has changed; they have less Treasury securities and higher deposits at Federal Reserve Banks. If the Fund desires to maintain the same asset mix and the same income as prior to intervention, it would activate transaction (3) in which it would buy Treasury securities in the market thereby increasing U.S. commercial bank reserves. ${ }^{4}$ Under these circumstances the net effect of intervention would again be an increase in foreign commercial bank reserves, no change in U.S. commercial bank reserves, and downward pressure on Treasury security yields.

Using SDR - In transaction (1) of Exhibit V, the Exchange Stabilization Fund sells SDR to the Foreign Central Bank and receives a foreign currency denominated deposit. In transaction (2) it spends this deposit to buy dollar deposits from a foreign commercial bank and transfers these deposits to Federal Reserve Banks. Again, since the Exchange Stabilization Fund keeps its dollar assets mainly in the form of Treastury sectrities, it will buy such securities (transaction (3)) and

\footnotetext{
If the Exchange Stabilization Fund were to buy securities directly from the U.S. Treasury, it would have increased Treasury balances at Federal Reserve Banks. This would have caused the Treasury to buy its securities in the market or reduce its sales of new securities. These transactions wonld have produced changes in commercial bank reserves and interest rates identical to transaction $(3)$.
}

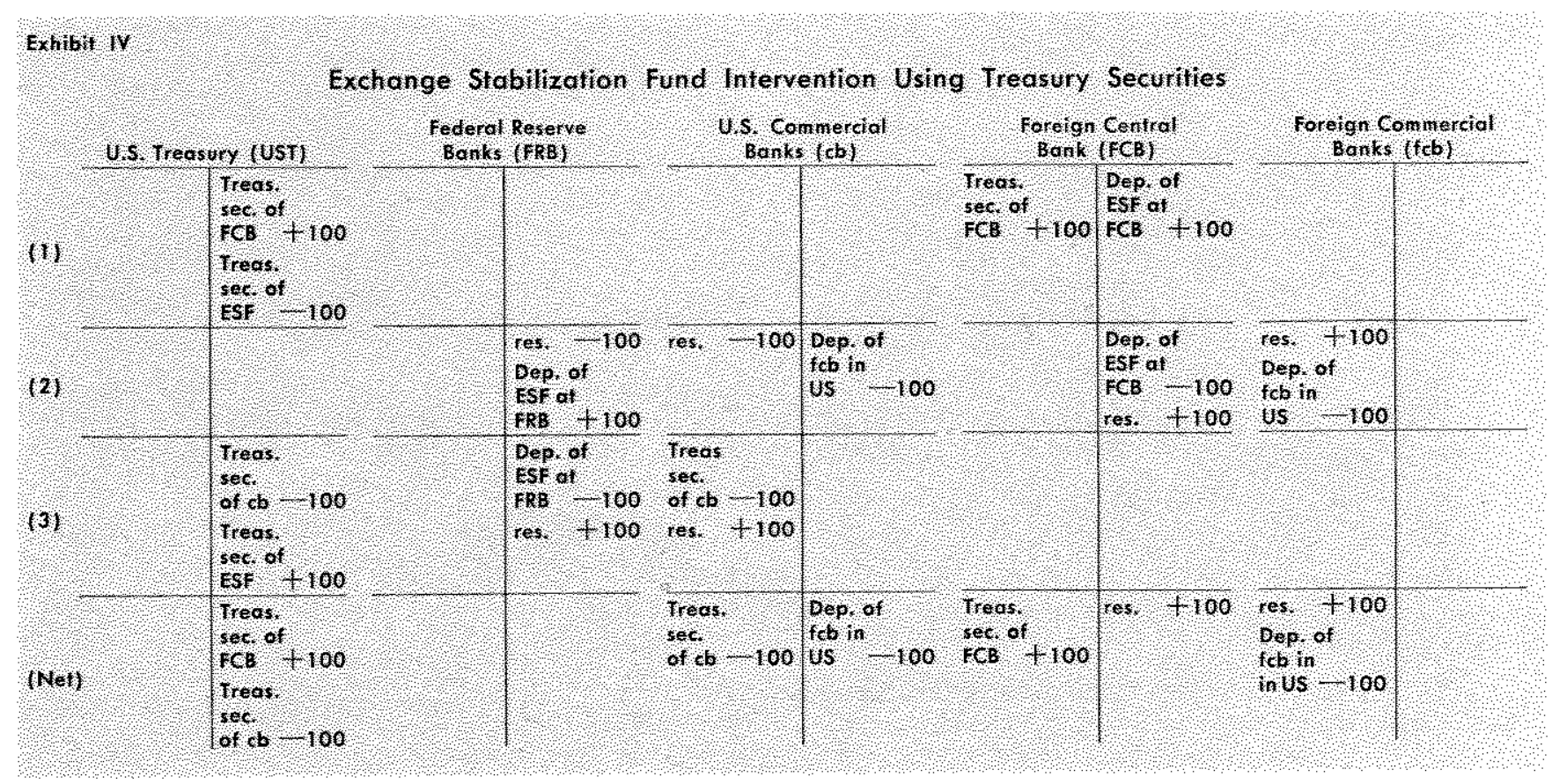




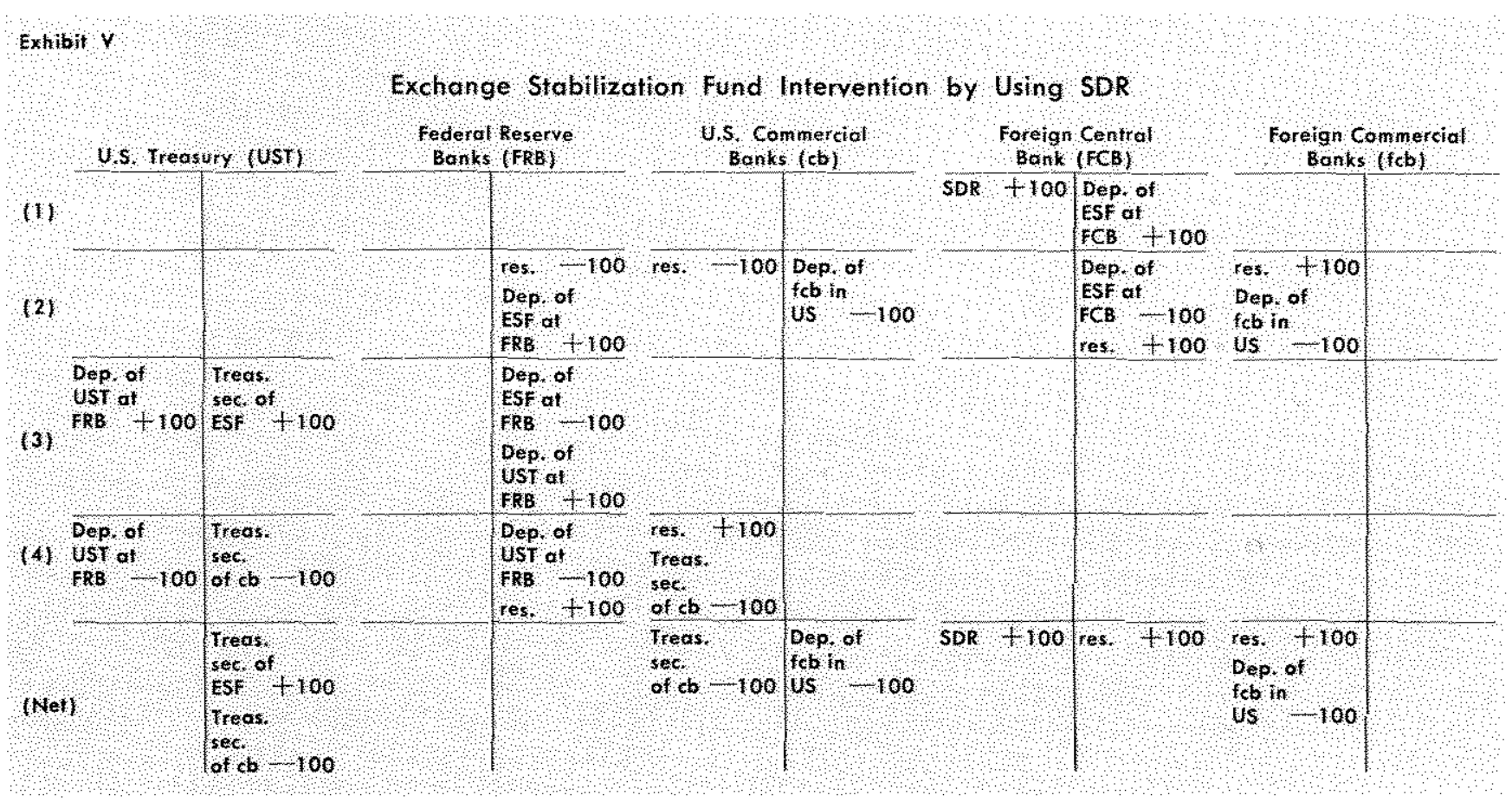

the U.S. Treasury will use these additional deposits to buy securities from U.S. commercial banks (transaction (4)). The net result of this type of intervention produces an increase in foreign commercial bank reserves and no change in U.S. commercial bank reserves. Furthermore, it lowers yields on Treasury securities.

\section{Summary and Conclusions}

The techniques described above exhaust the most frequently used methods of buying dollars in foreign exchange markets. Except for the case in which the Exchange Stabilization Fund is willing to issue additional SDR certificates, there are several results of intervention which are common to all the remaining methods:

1. In the absence of domestic fiscal and monetary policy actions to offset the impact of intervention, all intervention to support the dollar will lead to an expansion in foreign commercial bank reserves, pressure to expand the money stock and presumably upward pressure on the rate of inflation in affected countries.

2. Under the same conditions the reserves of U.S. commercial banks will not be affected and will not produce expansionary or contractive effects on the U.S. economy through monetary channels.

3. In all of these cases, and assuming no change in Treasury expenditures and receipts, there would be a decline in Treasury securities sold in the domestic market or an increase in the demand for such securities. This would exert downward pressure on U.S. Treasury security yields.

4. From the standpoint of economic repercussions caused purely by the acts of intervention, there is absolutely no difference in whether the intervention is undertaken by foreign central banks or by U.S. authorities.

5. In general, intervention in foreign exchange markets to support the value of the U.S. dollar is possible only through the cooperation of foreign central banks and their willingness to accept upward pressures on their commercial bank reserves. At the same time, as long as foreign central banks keep their dollar holdings in the form of U.S. Treasury securities, intervention will produce no impact on U.S, commercial bank reserves.

The exception is the case where the Exchange Stabilization Fund issues SDR certificates to the Federal Reserve and uses acquired deposits to intervene in foreign exchange markets. This method produces an increase in both foreign and U.S. commercial bank reserves. 